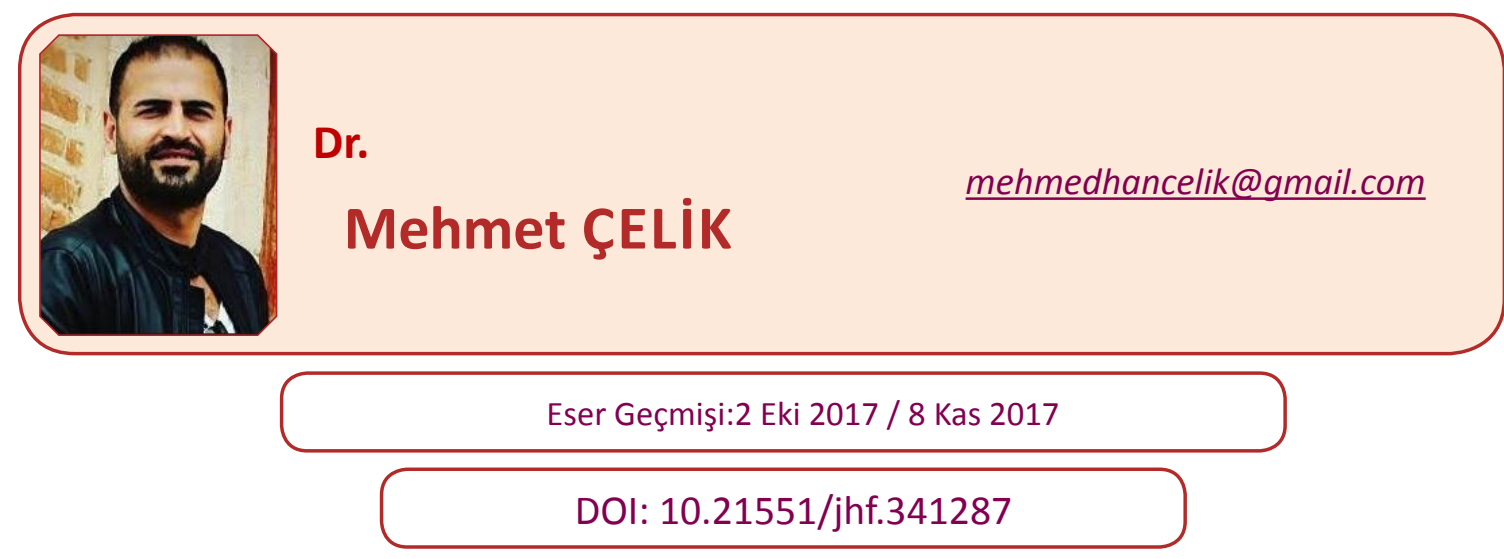

\title{
Kavramsal Olarak Diaspora, Ermeni Diasporası Ve Lübnan Ermeni Diasporası
}

\section{Conceptually Diaspora, Armenian Diaspora and Lebanon Armenian Diaspora}

\section{ÖZET}

Diaspora kavramının, tanım, sinıflandırma ve mevcut faaliyet noktasından yola çıkılarak diasporanın göç ve asimilasyonun teolojik ve ulus-devletçi anlayışlarına bir alternatif sunduğu ileri sürülmüștür. Ancak diaspora konusunda kavramsal olarak net bir konsept oluşmamıştır. Buradan hareketle diaspora, tanımlama açısından tartışmalı kavram olarak ortaya çıkmıştır. Zaman içerisinde klasikten çağdaşa, yerelden küresele ya da ilkelden moderne geçiş anlamında bir geçiş olduğu açıktır. Ermeni Diasporası; Ermeni sorunu, Ermeni milleti, anavatanı "klasik" unsurlarından zamanla evrimleşerek ve modernitenin koşullarına kendini uyarladığı için bu noktayı iyi bir şekilde ortaya çıkarmaktadır. Ayrıca diasporanın Lübnan hayatının her alanına (siyaset, ekonomi, toplum vb.) katılma sıklığı, yoğunluğu ve diasporanın Lübnan Devleti'nden gelen özerkliği Lübnan'ı ulus ötesi olarak konumlandırmıştır. Bu esasla Lübnan Ermeni Diasporasını diğer diaspora topluluklarından ayırmaktadır. Diaspora, anavatan ve milliyetçilik birbiriyle çakışan, çelişkili ve tartışmalı kavramlar olarak ortaya çıkmaktadır. Buradaki en önemli husus; bu kavramların Ermeni Diasporası algısında neyi çağrıștırdığıdır. Her biri kavramsal netlik içeren bu tanımlamalar, çalışmamamızda işlenecek kavramlar için belirgin önem arz etmektedir. Bu çalıșmada; Diaspora, Ermeni Diasporası ve Lübnan Ermeni Diasporası kavramsal olarak incelenecektir.

Anahtar Kelimeler: Diaspora, Ermeni, Lübnan , Ermeni Sorunu.

\section{ABSTRACT}

The concept of diaspora has been proposed as an alternative to the theological and nation-state conception of immigration and assimilation of diasporan by way of definition, classification and current activity point. However, there is no clear conceptual concept 
for diaspora. From this point on, diaspora emerged as a controversial concept in terms of definition. It is clear that there is a transition from classical to contemporary, from local to global, or from modal to primitive. Armenian Diaspora; The Armenian question positively reveals this point because the Armenian nation evolved from the "classical" elements of the motherland over time and adapted itself to the conditions of modernity. In addition, the frequency, intensity and diaspora's autonomy of Lebanon's State of Lebanon's participation in all areas of Lebanese life (politics, economy, society, etc.) This principle distinguishes the Lebanese Armenian Diasporas from other diaspora communities. Diaspora, motherland and nationalism are emerging as conflicting, contradictory and controversial concepts. The most important point here is; what these concepts evoke in the perception of the Armenian Diaspora. These definitions, each of which is conceptual clarity, are of particular significance for the concepts to be studied in our work. In this study; Diaspora, Armenian Diaspora and Lebanese Armenian Diaspora will be conceptually examined.

Keywords: Diaspora, Armenian, Lebanon, Armenian question.

\section{GíRİs}

\section{Diaspora Kavramı}

Tarihsel olarak, Yahudi halkının "vatanından zorunlu sürgününü" temsil etmek için kullanılan Diaspora terimi; "göç, sürgün, nostalji, gelenek ve dillerin sürdürülmesi, anavatana dönüş hayali" gibi kavramlarda da karşılık bulmuştur. Diaspora, kavramsal olarak; yeni anavatanda ulusal bir kimlik korunurken menșei evine dönme hayalidir ${ }^{1}$. Ancak Diasporadaki menşei ev algısı, diasporik hayal gücünün arzuladığı mitik bir yerdir. Bu anlamda 'menşei yeri' olarak görülen coğrafi bölgeyi ziyaret etmek mümkün olsa da dönüşü olmayan bir yerdir². Diaspora, fikri olarak birinci nesil göçmenlerin ve vatanın dışında doğan sonraki nesil torunları ifade emektedir. Diaspora, genellikle ortak kökten olan insanlara atıfta bulunurken, aynı zamanda anavatanı mutlak vatan ile paylaşmayan insanları da temsil etmektedir ${ }^{3}$. Esasında diaspora kavramının uluslararası perspektifte odaklandığı nokta şudur: Orijin (menşei) ülkesiyle aidiyetlerini (Maddi ve Manevi) koruyan ve devam ettiren, yabancı bir ülkeden göç etmiş etnik kökeni itibariyle azınlık bir gruptur ${ }^{4}$. Diaspora, tanımlama açısından tartışmalı kavram olarak ortaya çıkmaktadır. Zaman içerisinde klasikten çağdaşa, yerelden küresele ya da ilkelden moderne geçiş anlamında bir geçiş olduğu açıktır. Örneğin Ermeni sorunu, Ermeni milleti, anavatanı ve diasporası "klasik" unsurlarından zamanla evrimleşerek ve modernitenin koşullarına kendini uyarladığı için bu noktayı iyi bir şekilde ortaya çıkarmaktadır5.

1 Alfred, M. V. (2015). "Diaspora, Migration, and Globalization: Expanding the Discourse of Adult Education". 88.

2 Krikorian, M. R (2007). Almost Home: Perceptions Of Home And Homeland Among The Armenian Diaspora In Lebanon, Unpublished Master's Thesis, American Unıversity Of Beirut, Beirut, 20.

3 Yamashiro, J. H. (2013). "Working towards conceptual consistency in discussing 'diaspora' and 'diaspora strategies': Ethnicity and affinity in the case of Japan". Geoforum 59, 178.

4 Singh, M., Singh A.(2008). "Diaspora, Political Action, and Identity: A Case Study of Canada's Indian Diaspora". Diaspora, 17 (2), 153-4.

5 Krikorian, M. R (2007). Almost Home: Perceptions Of Home And Homeland Among The Armenian Diaspora In 
William Safran'ın yaklaşımıyla diasporalar, kendi orijin vatanları hakkında kolektif bir bellek, vizyon veya efsaneye sahip bireylerdir; fiziksel konumu, geçmişi ve başarıları ile birlikte atalarının vatanlarını ideal evleri olarak gören ve koşulları uygun olduğunda kendilerinin veya torunlarının geri döneceği ya da sonunda geri dönmesi gereken yer olarak görmektedirler ${ }^{6}$. Bir diaspora, sadece çeşitli nesillerdeki göçmen sayısından değil aynı zamanda proaktif bir şekilde kökeni itibariyle iddia eden nesillerden de oluşmaktadır. Bu terim, Anderson Benedıct'in dediği gibi; "uzun mesafe milliyetçilerin" çağırdığı anavatan dışında kalan sadece etno-ulusal grupları da kapsamamaktadır. Diğer "ulusötesi" olgularla birlikte diasporalar, genellikle küreselleşmeyi belirten ve bir dereceye kadar teşkil eden kavramlardır ${ }^{8}$. Diaspora, insanların göç ve etnik boyutlarının ötesinde, yerler ve inançlar arasındaki ilişkilerini anlamak için kullanılan analitik bir araç olarak da düşünülebilmektedir ${ }^{9}$. Diasporik kimliğin anahtar kelimesi "home" olarak düşünülürse eve dönüşü arzulayan bir kimlik etrafında görülebilmektedir. Diasporik kimlik, reform, dönüşüm, parçalanma ve asimilasyonu reddederken vatandaşlı̆̆ da arayan bir süreçtir ${ }^{10}$.

Klasik anlamda vatan kavramına atfedilen diasporalar, dönemsel olarak önemini yitirirken etnisiteler arası veya sinırlar ötesi Francophone, Anglofon ve Lusophone gibi dil kategorileri, 'Topluluk Diasporaları’ olarak kabul görmüștür. Vatan açısından bakıldığında, göç eden gruplar, büyük ölçüde asimile olmuş olsa dahi diaspora olarak kavramsallaştırılmıștır. Diasporalar, Akademik literatürde; Belarus, Brezilya, Kamboçya, Kolombiya, Mısır, İngiliz, Estonyalı, Etiyopyalı, Çingene, Hawaii, İgbo, İran, Irak, Japonca, Cava Dili, Kazakça, Letonca, Litvanyaca, Maya, Lehçe, Romence, İskoçya, Senegal, Somali, Sovyet, Sudan, Suriye, Tutsi ve Ukrayna Diasporaları, Dixie Diasporalar, Kuzey Amerikalı Diaspora, Beyaz Diaspora, Liberal Diaspora, Muhafazakâr Diaspora, Gay Diasporası, Kızıldeniz Diasporası, Sayısal Diaspora, Dijital Diaspora, Köktendinci Diaspora ve Terörist Diaspora gibi birçok alanda kategorize edilmiştir. Aynı zamanda Hindu, Sih, Budist, Konfüçyüs, Huguenot (Fransız Protestan), Müslüman ve Katolik Diasporaları da dâhil olmak üzere küresel dini cemaatlere sahip "Diasporalar" olarak nüfus formasyonunu oluşturmuştur ${ }^{11}$.

\section{Diaspora Kuramları}

Diasporayı kavramsallaştırma, tanımlama veya bu kavramı sınıflandırma ilk olarak John Armstrong tarafından; "belirli bir yönetim içinde toprak tabanına sahip olmayan herhangi bir etnik topluluk, yani; siyasi yönüyle nispi bir azınlık” olarak yapılmıştır ${ }^{12}$. Konseptin teorik

Lebanon, 30.

6 Laycock, J. (2012). “Armenian Homelands And Homecomings, 1945-9”. Cultural And Social History, 9 (1), 105.

7 Anderson, B. (1991). Hayali Cemaatler Milliyetçiliğin Kökenleri ve Yayılması. (Çev: İskender Savaşır), İstanbul: Metis Yayıncilik, IVA.

8 Björklund, U. (2003). "Armenians of Athens and Istanbul: the Armenian diaspora and the 'transnational' nation", Global Networks 3, 337.

9 Gallo, E. (2010). "Diaspora by Design? Multiple Allegiances and Belonging in Contemporary Global Catholicism". Diaspora, 19(1), 58.

10 Singh, M., Singh A.(2008). “Diaspora, Political Action, and Identity: A Case Study of Canada's Indian Diaspora”. 151 .

11 Brubaker, R. (2005). “The 'Diaspora' Diaspora”. Ethnic and Racial Studies, 28 (1), 3.

12 Ter-Matevosyan, V., Danielyan, H., Sisserian SV., Kankanyan N., and Shorjian, N.(2017). "Institutions and identity politics in the Armenian diaspora: the cases of Russia and Lebanon". Diaspora Studies, 10 (1), 65-66. 
anlayışının geliștirilmesi ise William Safran tarafından 1991 yılında yayımlanan bir makalede, "gurbetçi/göçmen azınlık toplulukları" olarak yapılmıştır. Özellikle Robin Cohen, diasporayla ilgili ilk monografi eserinde yukarıdaki tanımları tekrar edip tematik çerçevesiyle "Aynı etnik geçmişe sahip çatışmalar, savaşlar, soykırımlar veya mali konular gibi zor koşulların bir sonucu olarak farklı ülkelerde yaşayan bir grup insan." olarak tanımlamıștır ${ }^{13}$. Teorik çalıșmalarının yanı sıra vaka analizlerinin incelenmesine (Sheffer Dufoix, Esman, Sokefeld) dayanılarak, aşağıdaki tanımlamaları yapmak mümkün olmaktadır. Belli bir diaspora topluluğunun koşullarını şekillendiren kavramsal temalar şu temeller üzerinde şekillendirilmektedir ${ }^{14}$ :

"Homeland (Anavatan): Anavatanın, ev sahibi ülke ile diaspora üzerinden ilișkilerini sürdürmesi ve tesis etmesi..."

Hostland (Evsahibi): Ev sahibi ülkenin siyasi sistemi içerisinde diasporanın asimilasyonunu engelleyerek toplumsal, dini, irksal ve diğer türlerde hukuki, siyasi ve sosyal dinamiklerinin kurumsal olarak koruması ..."

Diasporanın tüm kategorilerini temel alırsak; Filistinliler, Kürtler, Tamiller, Çingeneler "Devlete bağlı ya da Devletsiz" olarak tasvir edilirken; Yahudi, Çinli, Hintli ve Ermeniler, "Tarihsel" olarak değerlendirilmektedir. Afrikalı Amerikalılar, Zenciler, Grek, Polonyalı ve Türkler, "Modern" olarak; Kore, Filipin, Tayland ve Rusyalılar, "Yeni başlayan"; Avrupa ve Asya' daki Amerikalılar, Amerika ve Kanada'daki Ukraynalılar ya da büyük çoğunluğu dağılmış olan Amerika'daki Yahudi ve Filistinliler, "Hareketsiz" olarak kategorize edilmiştir ${ }^{15}$.

Diaspora; devletsiz olarak siyasi aktör, nispi olarak da siyaset biliminde yeni bir trend haline gelmiştir. Diaspora çalışmaları kültürel çalışma, antropoloji ve sosyoloji olarak ortaya çıkmasına rağmen siyaset bilimi, 1990'lı yıllarda bu trendi başlatmıştır. Diaspora, ev sahibi devletlerin gözünde basit bir göç değildir. Dolayısıyla diasporalar, yerel ve uluslararası düzlemde siyasi bir aktör olmuşlardır ${ }^{16}$. Bir diaspora stratejisi, diasporalarla ilişkileri geliştirmeye ve yönetmeye yönelik açı ve sistematik bir siyaset inisiyatifi veya bir dizi siyasi girişimini hedeflemektedir. Başka bir deyişle; ilgili diasporaların doğasındaki farklılıklar, göç ettikleri ülkelerdeki farklılıklar, anavatandaki ekonomik ve kültürel koşullar ve anavatanın değişen özlemleri ile şekillendirilen çok çeşitli strateji türlerini ortaya çıkarmıştır ${ }^{17}$. Diasporalılar, bağlamsal istihbarat, küresel ağlar ekseninde girișimci yeteneği ve yaratıcı düşüncesi ile sınırlı yerel kaynaklara erişime sahiptir. Bu özellikler, diasporaların yenilik ve yabancılığa karşı yükümlülüklerini azaltmaya yardımcı olmaktadır. Aynı șekilde yabancı pazar bağlamında ticari faaliyetlerini sürdürmeye yönelik örgütsel ve yönetsel yeteneklerini de kullanmaktadırlar ${ }^{18}$. Diğer yandan diaspora, uluslararası meselelerde ve uluslararası

13 Ter-Matevosyan, V., Danielyan, H., Sisserian SV., Kankanyan N., and Shorjian, N.(2017). "Institutions and identity politics in the Armenian diaspora: the cases of Russia and Lebanon". 65-66.

14 Ter-Matevosyan, V., Danielyan, H., Sisserian SV., Kankanyan N., and Shorjian, N. (2017). "Institutions and identity politics in the Armenian diaspora: the cases of Russia and Lebanon". s.67

15 Sheffer, G. (2010). Diaspora Politics At Home Abroad. Cambridge: Cambridge University Press, 242

16 Bauböck, R., Faist,T.(2010). Diaspora and Transnationalism, Concepts, Theories and Methods. Amsterdam: Amsterdam University Press, 149

17 Yamashiro, J. H. (2013). "Working towards conceptual consistency in discussing 'diaspora' and 'diaspora strategies': Ethnicity and affinity in the case of Japan". 180.

18 Rana, Mohammad B., Elo, M. (2017). "Transnational Diaspora and Civil Society Actors Driving MNE 
politikada giderek önemli bir unsur haline gelmiştir. Esasında bu kavram, politikacılar ve göçmenler tarafından çeşitli amaçlara uygun seçilmiştir ${ }^{19}$. Diasporalılar, kendi menşei ülkeleriyle psikolojik, iletişimsel ve bazen maddi bağları proaktif olarak korumaktadır ${ }^{20}$. Fiona Adamson'a göre; ulus ötesi toplumların menşe ülkelerinde siyasi değişiklikler yapabilmeleri için üç yol vardır. Bunlar şunlardır ${ }^{21}$ :

“(1) Uluslar üstü alanlar içinde yeni siyasi kimliklerin ve söylemlerin oluşturulması;

(2) Ev sahibi ülke hükümetleri ve siyasi partileri, uluslararası örgütleri (STÖ) ya da STK'ları içerebilecek şebekelerin geliştirilmesi ve 'üçüncü şahıslar' ile lobi ilişkilerinin geliștirilmesi;

\section{(3) Ev devleti içindeki siyasi aktörlere maddi kaynakların doğrudan temini."}

Diaspora kavramının, tanım, sınıflandırma ve mevcut faaliyet noktasından yola çıkılarak diasporanın göç ve asimilasyonun teolojik ve ulus-devletçi anlayışlarına bir alternatif sunduğu ileri sürülmüștür. Ancak diaspora konusunda kavramsal olarak net bir konsept oluşmamıștır. Birçok milliyetçi hareketin öz olarak kabul ettiği 'Gerçek kimlikler' hakkındaki varsayımları ile uluslar üstü aidiyet duygusunu yeniden inşa etmek ve küresel düzeyde gerçekleşen hareketleri diasporadaki mevcut anlayış ekseninde ortaya çıkarmak zorlaşmıștır. Ayrıca çeşitli diaspora gruplarının hem diaspora hem de ev-devlet çevreleri tarafından yönlendirilen karşı iddialara sahip olması durumunda, diasporaların devlet dışı aktörler olarak özerkliği ne derecede olduğu belirsizdir. Dolayısıyla diasporaları kimlik temelli aktörler olarak kuramsallaştırmak veya ulus ötesi toplumsal hareketler üzerine ve mevcut teorik yaklaşımların üzerinden eleştirel anlamda incelemek gerekmektedir.

\section{Ermeni Diasporası}

Ermeni Diasporasının oluşum sürecine tarihi arka planıyla bakıldığında 11. Yüzyıl'a kadar götürülmektedir ${ }^{22}$. Ancak esas itibariyle Ermeni Diasporası, 1915 yılı ve sonrasında tanımlanmıştır ${ }^{23}$. Diasporada inşa edilmiş ve idealize edilmiş bir ulusal geçmişi temel alan "anavatan" vizyonuyla mutabık kalınmıştır. İkinci Dünya Savaşından sonraki yıllarda "anavatan"; Sovyet yetkilileri ve diaspora örgütleri tarafindan desteklenen bir stratejiye dönüşmüștür. Şöyle ki; diaspora tarafından Sovyet Ermenistan'ı, otoriter bir ulusal ev olarak meşrulaştırmak ve ülkeye geri dönüşü özendirmek için "anavatan” kavramı üzerinde propagandalar idealize edilmiştir. Bu yolla Ermeniler, Yahudiler gibi, atalarından bir vatanın

Internationalisation: The Case of Grameenphone in Bangladesh". Journal of International Management, 23 (1), 88.

19 Brinkerhoff, J.M. (2011). "David And Goliath: Diaspora Organizations As Partners In The Development Industry". Public Administration And Development Public Admin, 31 (1), 37.

20 Brinkerhoff, J.M. (2011). "David And Goliath: Diaspora Organizations As Partners In The Development Industry". Public Administration And Development Public Admin, 38.

21 Krikorian, M. R (2007). Almost Home: Perceptions Of Home And Homeland Among The Armeilan Diaspora In Lebanon, 25.

22 Baibourtian, A. (2009). "The Emergence of the Armenian Diaspora and Genesis of the Indo-Armenian Community". Diaspora Studies, 2 (1), 94.

23 Koinova, M. (2011). "Diasporas and secessionist conflicts: the mobilization of the Armenian, Albanian and Chechen diasporas". 338. 
geri dönüşüne dair ortak bir rüyanın anahtar niteliğini taşıyan bir arketip diasporasına dönüşmüştür. Esasında bu propaganda sonuç vermiş, 1946 ile 1949 arasında Amerika, Avrupa ve Ortadoğu'da yaşayan yaklaşık 100.000 Ermeni, Sovyet Ermenilerin "homeland" olarak tasvir ettikleri yerleşim çağrısını kabul etmişlerdi ${ }^{24}$.

Soğuk Savaş döneminde Sovyet Ermenistan ve Diaspora arasındaki etkileşim, tamamen olmasa da ideolojik bir çizgiyle bölünmüştür. Şöyle ki; Ermeni Devrimci Federasyonu, Sovyet Ermenistan'ı Ermeni milletinin meşru mirasçısı olarak görmemiş ve resmi irtibatlarını buna göre sınırlamıştı. Diasporadaki diğerleri ise, Sovyet Ermenistan'ı vatan kabul ederek onunla kültürel bağlar kurmuşlardı. 1964 yılında Sovyetler Birliği dışındaki çeşitli Ermeni cemaatleriyle irtibat kurmak için Sovyet Hükümet Ajansı kurulmuştu. Bu dönemlerde diaspora, iki büyük bölüme ayrılmıştır: Ermenistan'ın dışında yaşayan, ancak Sovyetler Birliği sınırları içinde (İç diaspora) yaşayan topluluklar ve Orta Doğu, Avrupa ve Amerika'da(Dış diaspora) yaşayan topluluklar olarak sınıflandırılmıştı. Diğer yandan bu toplulukları bir arada tutmaya ve ulusal kimliğini korumaya yardımcı olan toplum örgütleri, geleneksel siyasi partileri ve kiliseleri olmuştu. Sovyetler Birliği'ndeki bazı Ermeni cemaatleri, Etchmiadzin'e ${ }^{25}$ bağlı bazı kilise yapıları vardı. Ancak "dış" Diaspora'nın aksine, topluluk hareketi için siyasi yapıları olmamıştı. Bu yapılar, kendi okulları kümesiyle, kültürel ve atletik kulüplerle ve gençlik hareketleriyle sürüklenen siyasi partiler tarafından yönetilmişti ${ }^{26}$.

Sovyetler dışında Lübnan, Suriye, Mısır ve İran gibi Orta Doğu ülkeleri Ermeni Diasporası için ağırlık merkezi olarak kabul edilmişti. Bununla birlikte, 1970'li yılların başında ve ortalarında Ortadoğu'daki çatışmalardan (Lübnan İç Savaşı ve İran İslâm Devrimi) dolayı Ermenilerin toplu göç etmesi ile ağırlık merkezinin Ortadoğu'dan Kuzey Amerika'ya geçişine neden olmuştu. Bu aynı zamanda, Ermeni-Amerikan topluluğunun entegre olmasına, siyasi işbirliğine ve dolayısıyla ev sahibi milletin siyasi hayatlarına aktif olarak katılmaya neden olmuştu. Ortadoğùdan gelen Ermeni nüfusunun odak noktası, siyasi gündemlerinin bir parçası olarak lobiciliğe kaymıştı. Dolaysıyla bu durum, Kuzey Amerika〉daki mevcut toplulukların faaliyetlerine yenilenmiş bir ivme kazandırmıştı. Başlangıçta bu faaliyetler çoğunlukla "Soykırım" tanımaya odaklanmıştı. Ancak 1991 yılında Ermenistan'ın bağımsızlığı ile birlikte, yeni cumhuriyete insani ve ekonomik yardım üzerine odaklanılmıştı. 19881991 yılları arasındaki dönem, "Karabağ Olayları"nın başlaması, Aralık 1988 depremleri ve Ermenistan'ın bağımsızlık ilânı gibi olaylar, Ermenistan-Diaspora ilişkilerine yeni dinamikler getirmiști. Diasporada, kimlik koruma ve "Soykırım” tanımaya odaklanan geleneksel gündem varlığını devam ettirmişti ${ }^{27}$. Ancak yeni ortaya çıkan bir devletin hayatta kalması ve refahı için yeni bir endişe oluşturulmuştu. Bağımsızlık hareketi ve Kuzey Ermenistan'daki yıkıcı deprem, diasporanın Ermenistan'a yönelik çabalarında etkili olmuştu. 1988 yılı öncesinde Ermenistan'da yaygın düşünce Cumhuriyetin diasporayı (kültürel ve kimlik bakımından)

24 Laycock, J. (2012). “Armenian Homelands And Homecomings, 1945-9”. 103-104.

25 Ermeniler tarafından kutsallığını kabul edilen aynı zamanda doktirinel ve idari organizasyon olarak Ermeni kiliselerinin dini merkezi olarak görülen yerdir. Messerlian, Z. M. (1963). Armenian Representation In The Lebanese Parliament. 46.

26 Policy Forum Armenia. (2010). Armenia-Diaspora Relations: 20 Years Since Independence. Armenia: A publication of Policy Forum Armenia, 8.

27 Diaspora Ermeni örgütleri arasında Türklere karşı genel olarak hasmane duygulara sahip olmalarının ve bu duygularının bu dönemdeki politikanın bir parçası haline getirerek,"bilerek veya bilmeyerek" Türk insanına düşmanlığı örgütlemek yolunu seçmiş olanları vardır. Akçam, T. (2000). Ermeni Tabusu Aralanırken: Diyalogdan Başka Bir Çözüm Var mı?. İstanbul: Su Yayınları, 35. 
desteklediği, 1988 yılından sonra ise savaş ve depremlerle tahrip olan Cumhuriyeti, kriz ortamından çıkarmak için desteklemeye ve yardımları sürdürmeye şartlandırıldığıydı ${ }^{28}$.

Diaspora toplulukları, örgütlü ve gayri resmi faaliyetler vasıtasıyla birbirleriyle aktif olarak bağlar kurmayı amaçlamışlardı. Özellikle 1991 yılında Ermenistan Cumhuriyeti'nin bağımsızlığı, diasporanın "ev sahibi" devletlerde giderek daha kök salmasına ve daha sivil katılımın sağlanmasına neden olmuştu. Aynı zamanda Ermenistan’a yönelik bir yönelimin yanı sıra, ulus aşırı sembolü olan 'vatan' anlayışının geleneksel diaspora yaklaşımıyla yeniden canlandırılmasına da neden olmuştu ${ }^{29}$. Bağımsız Ermenistan'ın ilk Cumhurbaşkanı Levon TerPetrosyan, yeni Cumhuriyet'te diasporaya özgü herhangi bir kurumsallaşmaya gitmemişti. Levon Ter-Petrosyan'ın 1991'den 1998 yılına kadar görev süresi boyunca Ermenistan ve diaspora arasındaki ilişkiler gerilmişti. Ter-Petrosyan, diaspora temelli Taşnak Siyasi Partisi'ni yasaklayıp bazı liderlerini de hapsederek anayasada çifte vatandaşlığa iliş̧kin açık bir yasakla mevcut diasporanın büyük bölümlerini çıkararak diasporayla ilișkileri yabancılaștırmıștı. Ter-Petrosyan, diaspora eleştirisine gerekçe olarak; diaspora politikalarının rejimi tehdit ettiğini belirtmişti ${ }^{30}$. Ancak ikinci Cumhurbaşkanı Robert Koçaryan, Ermenistan-Diaspora ilişkisini kurumsallaştırmak ve yönetmek için ilk girişim olarak ortaya çıkmıştı. Dışişleri Bakanlığı, Bakan Vartan Oskanyan başkanlığında ilki Eylül 1999 yılında, ikincisi Mayıs 2002 yılında ve üçüncüsü Eylül 2006 yılında olmak üzere "Ermenistan Diaspora Konferansları" düzenlemişti. Bu organizasyonlardaki amaç, bağlı olmayan bir diasporayı devlete bağlamaya çalışmak olmuştur. Bu konferanslara (Armenia-Diaspora Conferences; the Ministry of Diaspora) davetiye ve konuşmacı olarak, Ermenistan Devleti yetkilileri görevlendirilmişti. Ayrıca Diaspora örgütleri çatısı altında hayır kurumları, lobi grupları, kulüpler, kiliseler, siyasi partiler tercih edilmişti. Böylelikle örgütsel bağları olmayan kișiler hariç tutulmuştu ${ }^{31}$.

Devlet-Diaspora ilişkilerinin nasıl göründüğü konusunda üzerinde inşa edilmesi gereken sembolik bir modele sahiplerdir. Birçok eski komünist devletin aksine Ermeni Devlet elitleri, siyasi bir kültüre yönelme ve sembolik bir sözcük dağarcı̆̆ına sahip olma yeteneklerine göre diasporaları, yakın ya da uzak olarak inşa etmektedir. Son zamanlarda "Diaspora yönetimi" kurumsallașmıștır. Bu siyasi kültür, Sovyet yönetiminin mirası olduğundan, Ermeni Diasporasının daha yakın, daha "sadık" ve daha az zahmetli kısmı olarak benimsenmiştir. Rusya Ermenileri’nin ekonomik ve siyasi nüfuz ve arzuları göz önüne alındığında, en azından "diasporik faaliyetler" yapanların sadakati ve ortak bir siyasi kültüre dayalı yakınlık varsayımları, "zihniyet" olarak da tasvir edilebilmektedir. Milletvekilleri ve Diaspora Ermenileri, diasporanın potansiyelini kullanmayı ve Ermenistan’ın geliştirilmesine yardım etmeyi amaçlamışlardı. Bakanlığın diğer önceliği, esas olarak etnik köken itibariyle yeniden canlanma olan Hayadartsutyun'dur. Bu sözcük, Ermenice geri gönderme sözcügüne benzer şekilde, bakanlığın Ermenileri, "yeniden Ermenileştirme"yi öncelik vermelerini ve "eve taşımak için kendilerine çekmeye " olarak çağrıştırmıştır ${ }^{32}$.

28 Policy Forum Armenia. (2010). Armenia-Diaspora Relations: 20 Years Since Independence. 9.

29 Kasbarian, S. (2013). "Diasporic Voices from the Peripheries - Armenian Experiences on the Edges of Community in Cyprus and Lebanon". The Cyprus Review, 25 (1), 81.

30 Cavoukian, K. (2013). "Soviet mentality?" The role of shared political culture in relations between the Armenian state and Russia's Armenian diaspora". Nationalities Papers, 41 (5), 716.

31 Cavoukian, K. (2013). "Soviet mentality?" The role of shared political culture in relations between the Armenian state and Russia's Armenian diaspora". 716.

32 Cavoukian, K. (2013). "Soviet mentality?" The role of shared political culture in relations between the Armenian 
Ermeni Devleti, 1999 yllından başlayarak, yaklaşık on yıl süren adım adım bir politika deklarasyonu sonrasında önemli bir girișimi olarak "Diaspora yönetimini öncelikli kılmaya" başlamıştır. Sovyetler Birliği'nin çökmesine rağmen Rus Ermeni Cemaati'nin büyümesinden hareketle birçok Rus Ermeni'si giderek artan ekonomik nüfuzuyla bu tür girişimlere önemli bir katkı sunmuştur ${ }^{33}$. Ayrıca kurumsal örgütlenmenin en önemli bir kimliği olan diaspora, 2007 yılında Ulusal Güvenlik Stratejisi olarak kavramsallaştırılmış ve kurumsal bir kimliğe de dönüştürülerek 2008 yılında Diaspora Bakanlığı kurulmuştur ${ }^{34}$.

Ermenistan-Diaspora ilişkileri, 20. Yüzyılın ilk yarısından başlayarak Birleşik Devletler'in diaspora siyaseti ve dernek faaliyeti üzerinde de etkisini göstermiştir. Kendi menşei ülkelerinden fiziksel uzaklıklarına rağmen 20. Yüzyılda Birleşik Devletler'deki siyasi faaliyetleri, Ermenistan hükümetleri tarafından göz ardı edilmemişti. Bu hükümetler, siyasi ve mali desteğini toplamak için zaman zaman gurbetteki topluluklar üzerinde siyasi nüfuzlarını genişletmeye çalışmıștı. Çoğu zaman, diaspora siyaseti ve hizipçilik, devletin aktörlerinin eve döndügü ve yerli ve yabancı politikacıların meşruiyetini saran anlaşmazlıklara, yurtdışı destekçilerine ve vatan hükümetlerinin eleştirenlere karşı da olmuştur ${ }^{35}$.

Günümüzde Ermeni Diasporası küreselleşmiştir. Şöyle ki; büyük topluluklar halinde Rusya, ABD, Fransa, Gürcistan ve Lübnan`da ikâmet etmektedirler. Kolkata`dan Los Angeles`a ve Buenos Aires`e, St. Petersburg`dan Sydney〉e, yıllar boyunca dağılmıştır. Nüfus istatistikleri net olmamakla birlikte bazı iddialara göre Rusya'da yaklaşık 2 milyon, ABD'de 1 milyondan fazla, Fransa'da 500 bin, Gürcistan'da 350 bin, İran'da 250 bin, Suriye'de 190 bin, Lübnan'da 140 bin, Arjantin'de 130.000'dir ${ }^{36}$. Bahse konu olan bu göçler 1915 yılından sonra gerçekleşmiştir. Bu göçler, Lübnan'da, İran'da ve Suriye'de geniş topluluklar halinde gelişmiştir. 1975 yılına kadar ABD ve Kanada'da 500.000'den fazla İtalya, İsviçre, Avusturya, Romanya, Bulgaristan, Avustralya ve Hindistan gibi ülkelerdeki aktif toplulukların yanı sıra Fransa'da 200.000'den fazla, Güney Amerika'da da 100.000'den fazla nüfusa sahip Ermeniler bu ülkelerde faaliyet göstermişlerdir ${ }^{37} .1915$ sonrasında özellikle Lübnan, Suriye, Filistin ve İran, Etiyopya, Uzak Doğu, Latin Amerika (özellikle Arjantin), Yunanistan, İtalya ve İngiltere gibi ülkelere dağılmıştı. Fakat Fransa ve ABD'de çok büyük ve köklü Ermeni Diaspora toplulukları ortaya çıkmıștır ${ }^{38}$. Dünya çapındaki Ermenilerin dağılımına ilişkin çeşitli sayılar aşağıda gösterilmiştiri3

state and Russia’s Armenian diaspora". 717.

33 Cavoukian, K. (2013). "Soviet mentality?" The role of shared political culture in relations between the Armenian state and Russia's Armenian diaspora”. 713.

34 Ter-Matevosyan, V., Danielyan, H., Sisserian SV., . Kankanyan N., and Shorjian, N.(2017). "Institutions and identity politics in the Armenian diaspora: the cases of Russia and Lebanon". 64

35 Yousefian, S.N.(2014). "Picnics for Patriots: The Transnational Activism of an Armenian Hometown Association". Journal of American Ethnic History, 34 ( 1), 32.

36 Baibourtian, A. (2009). "The Emergence of the Armenian Diaspora and Genesis of the Indo-Armenian Community". 98.

37 FCO9/3073/WST 245/1.

38 Cohen, R. (2008). Global Diasporas. New York: Routledge, 53.

39 Cohen, R. (2008). Global Diasporas. 52. 


\begin{tabular}{|c|c|c|c|c|}
\hline Ülke & $\mathbf{1 9 6 6}$ & $\mathbf{1 9 7 6}$ & $\mathbf{1 9 8 5}$ & $\begin{array}{c}\text { Son } \\
\text { veriler }\end{array}$ \\
\hline & & & & $\begin{array}{c}2,971, \\
650 \\
(2007)\end{array}$ \\
\hline & 560,000 & $?$ & 560,000 & \\
\hline $\begin{array}{c}\text { Rusya } \\
\text { (1991'e } \\
\text { kadar } \\
\text { SFSC) }\end{array}$ & 330,000 & $?$ & 360,000 & $\begin{array}{c}264,822 \\
(2007)\end{array}$ \\
\hline Diğer & 60,000 & $?$ & $?$ & $?$ \\
\hline $\begin{array}{c}\text { SSCB } \\
\text { eski }\end{array}$ & $?$ & & & - \\
\hline $\begin{array}{c}\text { TOPLAM } \\
\text { SSCB }\end{array}$ & & & & - \\
\hline $\begin{array}{c}\text { ABD ve } \\
\text { Kanada }\end{array}$ & 450,000 & 500,000 & 800,000 & 945,615 \\
\hline Türkiye & 250,000 & $?$ & 70,000 & 115,000 \\
\hline İran & 200,000 & $?$ & 200,000 & 202,000 \\
\hline Fransa & 200,000 & $?$ & 300,000 & 273,000 \\
\hline Lübnan & 180,000 & $?$ & 200,000 & 260,000 \\
\hline Suriye & 150,000 & $?$ & 100,000 & 200,000 \\
\hline Arjantin & $?$ & $?$ & 100,000 & 132,000 \\
\hline Diğer & 570,000 & $?$ & 233,000 & $?$ \\
\hline Toplam & & $?$ & & $?$ \\
\hline $\begin{array}{c}\text { TOTAL } \\
\text { (Dünya } \\
\text { çapında) }\end{array}$ & & $?$ & & \\
\hline
\end{tabular}

1989 yllı itibariyle Komünizmin çöküşünden sonra Ortadoğu ve eski Sovyetler Birliği'nden gelen Ermeni nüfus, önemli ve artan bir şekilde Diaspora toplulukları olarak Fransa ve ABD'ye yerleşmişti. ABD Ermenilerinin ekonomik açıdan diğer Ermeni Diaspora topluluklarından daha yüksek bir yaşam standardına sahip oldukları bilinmektedir. Bunun yanı sıra ABD'deki diğer yerleşik etnik gruplarla da entegre olmuşlardır. Bununla birlikte, belki de bu örgütsel faaliyetin son zamanlardaki en önemli değişimi, Washington'da güçlü bir Ermeni siyasi lobisinin büyümesidir. ABD'deki Ermeni organizatörler, Kongre'de 24 Nisan'ı anmak ve ulusal bir gün ilân etmek için bir kanun tasarısını desteklemişlerdi. Esas itibariyle bu lobiciliği Yahudi-Amerikalılardan öğrenmişlerdir. Bahse konu olan bu Lobi, ortak sergilere sponsorluk, konferanslar ve yayınlar olarak ortaya çıkmıştı. Dolayısıyla Soğuk Savaşın bitimiyle değișen jeopolitik özelliklerden tam olarak yararlanmışlard ${ }^{40}$.

ABD dışında Ermeni Diasporasının büyük bir çoğunluğu Rusya'da yaşamaktadır. Bu

40 Cohen, R. (2008). Global Diasporas.53. 
diaspora, organizasyon olarak zayıf ve bağlantısızdır. Bu sebeple milli kimliklerini, din, dil ve kültürleri korumaları zorlaşmıştır. Rusya'nın bazı bölgelerinde Ermeniler arasında kendi kimlik, yerli dil ve geleneklerini neredeyse kaybetmişlerdir ${ }^{41}$. Ayrıca diasporik kimliği ve kurumları da "1915 Olayları" ile bağlantılı olarak eski nesiller tarafından tanımlanmıştır. Özellikle en etkili diaspora grubu olan "Taşnaklar" olarak bilinen Ermeni Devrimci Federasyonu (Armenian Revolutionary Federation) tarafından yapılmıştır. Ancak bu dönemlerde Ermeni göçleri de yaşanmıştır. Önce Ortadoğu sonra Batı Avrupa ve Amerika'ya olmuştur. Ayrıca 1990’lı yıllarda “Karabağ Olayı"nın verdiği ekonomik çöküş de toplu göçe neden olmuştur².

\section{Lübnan Ermeni Diasporası}

Dünyadaki farklı Ermeni grupları, 1915 sonrası dönemde farklı kimlikoluşum süreçlerine girmiştir. Her Diaspora topluluğu kendi özelliklerine ve barınma geçmişine sahip olsa da 1915 sonrası dönemde Diasporanın en yoğunlaștığı yer Lübnan'daki Ermeni Diasporası'dır. Lübnan, Ermeni Diasporasının Lübnan'daki merkezi öneminin yanı sıra oldukça karmaşık doğasını da yansıtmaktadır ${ }^{43}$. Lübnan, Ortadoğu'daki Ermeni toplulukları için tarihi olarak diasporik merkez üssü olmuștur ${ }^{44}$. Şöyle ki; Lübnan ticaret diasporası, başlangıçta iki ayrı grup olarak; tüccar ve emekçiden oluşmuştu. 17. Yüzyıl ile 19. Yüzyıla kadar nispeten müreffeh olan bağımsız tüccarlar, Ortadoğu ve Avrupa arasındaki ticaret hacmini arttıran ağlar kurmuşlardı. Önemli bir aşaması Mısır' da, Livorno'da, Marsilya ve Manchester'da gerçekleşmiştir. Beyrut'un etrafındaki bölge olan Lübnan, modern dünya ekonomisine oldukça entegre olmuş ve önemli bir ticaret, ulaşım, iletişim ve finans ekseninde durmuştur. Suriye'nin finansal sermayesi olan Beyrut, yabancı bankalar ve sigorta şirketleri ile finans merkezi olmuştur. Demiryolları ve liman şirketleri, ipek atma endüstrileri, bankalar, oteller ve eğitim kurumları, diğer Ortadoğu ülkelerinde boyutları bulunmayan bir burjuvazinin temelini oluşturmuştu ${ }^{45}$.

Ermeniler, Ortadoğu'da özellikle; İran, Lübnan ve son zamanlarda Suriye'de siyasi ve sosyal olarak oldukça organize olmuşlardır. Özellikle Lübnan'da önemli bir nüfusa sahiplerdir. Ulusal kimliklerini (dil, din ve kültür) korumakla kalmayıp yeni nesillere de aktarmaktadırlar ${ }^{46}$. Lübnan'daki Ermeni toplumu, 3 tema üzerinde; kimlik, kurum ve siyasi entegrasyon üzerine kategorize olmuştur. Bu esas da Lübnan'ı tüm çevresel Ermeni toplumunun merkezi haline getirmiştir. Özellikle Ermeni Apostolik Kilisesi, Lübnan'daki Ermeni Diaspora açısından sadece dini değil aynı zamanda ulusal, kültürel ve eğitim yaşamından önemli bir kurum haline gelmiştir ${ }^{47}$.

41 Ter-Matevosyan, V., Danielyan, H., Sisserian SV., . Kankanyan N., and Shorjian, N.(2017). "Institutions and identity politics in the Armenian diaspora: the cases of Russia and Lebanon". 65

42 Koinova, M. (2011). "Diasporas and secessionist conflicts: the mobilization of the Armenian, Albanian and Chechen diasporas". 338.

43 Krikorian, M. R. (2007). Almost Home: Perceptions Of Home And Homeland Among The Armenian Diaspora In Lebanon. 33.

44 Kasbarian, S. (2013). "Diasporic Voices from the Peripheries - Armenian Experiences on the Edges of Community in Cyprus and Lebanon". 81.

45 Cohen, R. (2008). Global Diasporas.31.

46 Ter-Matevosyan, V., Danielyan, H., Sisserian SV., . Kankanyan N., and Shorjian, N. (2017). "Institutions and identity politics in the Armenian diaspora: the cases of Russia and Lebanon". 65.

47 Ter-Matevosyan, V., Danielyan, H., Sisserian SV., . Kankanyan N., and Shorjian, N. (2017). "Institutions and identity politics in the Armenian diaspora: the cases of Russia and Lebanon”.69. 
Lübnan'ın siyasi ve sosyal çatışma ortamı, kırılgan ekonomisi, kronik zayıf bir devlet algısı ve sayısız diğer faktör göz önüne alındığında diasporanın yer aldığı örgütlü araçlar ve Lübnan'daki başlıca sosyo-politik gruplarla olan ilişkisi, Lübnan Ermeni Diasporasını diğer diaspora topluluklarından ayırmaktadır. Diasporanın Lübnan hayatının her alanına (siyaset, ekonomi, toplum vb.) katılma sıklığı, yoğunluğu ve diasporanın Lübnan Devleti'nden gelen özerkliği Lübnan'ı ulus ötesi olarak konumlandırmıştır ${ }^{48}$. Lübnan'daki Diasporanın yurtiçi kamusal konularda yer almasının önemli bir özelliği, Lübnan'daki siyasetin derin ayrımcı karakteri ve bunların her zaman olmasa da, genellikle yurtdışında çoğaltılması olmuştur. Genel olarak diasporaların özelliği olan nispeten tekdüze bir dizi siyasi faaliyetin aksine, Lübnan politikasındaki derin ve kronik bölünmeler, diasporadaki daha büyük dağılışı ortaya çıkarmıştır ${ }^{49}$. Lübnan, Ermeni algısında sık sık “İkinci vatan» ya da « İkinci başkent « olarak anılmaktadır. Dilsel, dini, mesleki ve yerel farklılıkların nötralize edilmesi kısa sürede gerçekleşmiştir. Bu değişimin başlıca araçları Ermeni siyasi partileri, özellikle de Ermeni Devrimci Federasyonu (Armenian Revolutionary Federation) olmuştur ${ }^{50}$. Ermeni Devrimci Federasyonu Partisi, Sosyal Demokrat Hınçak Partisi ve Liberal Demokrat Ramgavar Partisi, eğitimin de için bulunduğu yoğun propaganda ve kitlesel seferberlik kullanmak suretiyle 1930'lu yılların ortalarından sonra yeni siyasallaşmış kitleler arasında "güçlü ve modern bir pan-ulusal duygusu" gibi bir kimlik aşılama amacıyla ortaya çıkmışlardı. Bu süreçlere Lübnan'daki mevcut konfesyonel sistem yardım etmiştir. Dahası Ermeni cemaatinin kendi milli kimliğini korumak ya da başka bir anlamda kurmak için birçok firsat sağlamıştır. Dolayısıyla kimlik açısından bakıldığında Lübnan, Ermeni Diasporası için merkezi bir öneme sahip olmuştur. Şöyle ki; yakın tarihte Lübnan Parlamentosunun Ermeni üyesi olan ve aynı zamanda yüksek rütbeli Taşnak yetkilisi Hagop Pakradounian ile yapılan bir röportajda Lübnan'ın Ermeni Diasporası için merkezi bir öneme sahip olmasını birbiriyle ilişkili altı faktör olarak şöyle sıralamıştır:

Ermeni nüfus yoğunluğu.

Lübnan'ın konfesyonel sistemi ve Ermeni cemaatinin resmen tanınmış ve hak verilmiş tek ülke olduğu gerçeği.

Ermeni siyasi partilerinin merkezi karargâhının yanı sıra Ermeni Apostolik Kilisesi ve diğer bazı Ermeni örgütleri barındırıyor olması.

Lübnan'ın demografik yapısı.

Birçok Ermeni-Lübnanlı öğretmen, rahip, sanatçı ve gazeteci diğer ülkelerdeki Ermenilerle olan yardım işbirlikleri.

Lübnan Devleti'nin demokratik yapısının Ermenilere Ortadoğu'daki diğer yerlerden daha

\footnotetext{
48 Skulte-Ouaiss, J., Tabar, T. (2014). "Strong in Their Weakness or Weak in Their Strength? The Case of Lebanese Diaspora Engagement with Lebanon, Immigrants \& Minorities Historical Studies in Ethnicity". Migration and Diaspora, 33 (2), 142-143.

49 Skulte-Ouaiss, J., Tabar, T. (2014). "Strong in Their Weakness or Weak in Their Strength? The Case of Lebanese Diaspora Engagement with Lebanon, Immigrants \& Minorities Historical Studies in Ethnicity”. 146

50 General CIA Records, CREST, CIA-RDP80-00809A000700030265-3.
} 


\section{fazla özgürlük ve çalışma olanağı veriyor olması. ${ }^{51}$}

Yukarıdaki nüfus faktörü dışında diğer olgular isabetlidir. Şöyle ki; Lübnan'daki nüfus diğer ülkelerden daha fazla değildir ${ }^{52} .2002$ yılında Jinishian Anma Programı tarafından yürütülen bir araştırmada Ermeni nüfus sayısı 100.000 ila 150.000 arasında değişmektedir. Bu istatistiksel veriye bakıldığında Rusya, Amerika Birleşik Devletleri, Gürcistan, Fransa ve Ukrayna'dan sonra Ermenistan dışındaki en büyük altıncı toplulukla ilgilidir. Bununla birlikte, bu noktalar hakkında ilginç olan, ev sahibi ülkenin siyasi ve toplumsal ortamında Ermeni topluluğunun aidiyet, gelenek ve geleneklerini korumasına yardımcı olan referanslarıdır ${ }^{53}$.

Lübnan, Ermeni Diasporasının eğitim ve kültür merkezidir. Ermeni Diasporası açısından modern çağın anavatanıdır. Ermeni Şair Mushegh Ishkan bir yazısında Lübnan'ı “ Diasporadaki kültürün merkezi kalesi" olarak tasvir etmesi bu tanımı teyit etmiştir ${ }^{54}$. Bunun yanında Antelias'taki Katoğigosluğun 1915 olaylarından sonra Ermeni toplumunun yeniden organize edilmesinde etkili olmuştur. Ermeni Apostolik Kilisesi, dini bir kurum olmasının yanı sıra Lübnan Ermeni Diasporasının milli, kültürel ve eğitim yaşamında da önemli bir kurum haline gelmiștir ${ }^{55}$. Lübnan'daki kilise gibi diğer tüm Ermeni organizasyonların amacl, Lübnan'daki Ermeni Diasporasının Ermeni milli kimliğini güçlendirmek ve sürdürmektir ${ }^{56}$.

Lübnan'da Ermeni cemaatlerinin örgütlenmesini kolaylaştıran bir diğer faktör Lübnan'ın coğrafik yapısıdır. Mevcut toplu yerleşim alanları sayesinde Beyrut ve Lübnan'daki Ermeni mahalleleri bugüne kadar oluşturulmuş ve korunmuştur ${ }^{57}$. Lübnan'ın Ermeni Diasporası için merkezi bir önem kazanmasının iki temel nedeni vardır. Birincisi kültürel şartlarıdır. Şöyle ki; diaspora açısından Lübnan, Ermeni kimliğini muhafaza etme (Hayabahbanum) çabalarını herhangi bir ülkeden daha uzun süren ve mümkün olan en iyi koşullardan biri olarak nitelendirilmektedir. İkincisi ise siyasidir. Ortadoğu genelinde ve özellikle Lübnan'daki Diasporanın idealize edilmiş olgularının gelişimi için özel önemi olan diasporanın nihai hedefi, Ermenilerin gelecekte anavatanlarına dönüşü olarak öngörülmüştür. Ayrıca Ortadoğu toplumlarının vatanlarına coğrafi olarak yakın olması bu yüksek hedefi gerçekleşmesine daha yakın hale getirmiş gibi gözükmektedir ${ }^{58}$. Her iki argüman, 1970’li yılların kritik bağlamında birbirlerini güçlendirmiști. Bir yandan, Lübnanlı Ermeni cemaatinin kültürel yaşamı, özellikle

51 Krikorian, M. R. (2007). Almost Home: Perceptions Of Home And Homeland Among The Armenian Diaspora In Lebanon. 36-37.

521925 yılında Beyrut'ta bir bölgedeki yeni gelmiş Ermeni göçmen sayısı 45.000 kadardır. Laçiner, S.(2013). Ermeni Sorunu, Diaspora ve Türk Dı̧̧ Politikası. Ankara: Usak Yayınları, 97.

53 Krikorian, M. R. (2007). Almost Home: Perceptions Of Home And Homeland Among The Armenian Diaspora In Lebanon. 37.

54 Abramson, S. (2013). "Lebanese Armenians; A Distınctive Community In The Armenian Diaspora And In Lebanese Society". The Levantine Review 2 (2), 201.

55 Ter-Matevosyan, V., Danielyan, H., Sisserian SV., Kankanyan N., and Shorjian, N. (2017). "Institutions and identity politics in the Armenian diaspora: the cases of Russia and Lebanon". 68.

56 Ter-Matevosyan, V., Danielyan, H., Sisserian SV., Kankanyan N., and Shorjian, N. (2017). "Institutions and identity politics in the Armenian diaspora: the cases of Russia and Lebanon". 69.

57 Ter-Matevosyan, V., Danielyan, H., Sisserian SV., Kankanyan N., and Shorjian, N. (2017). "Institutions and identity politics in the Armenian diaspora: the cases of Russia and Lebanon". 75. Ayrica Bkz. Ek-3.

58 Ghoukassian, K. D. (2009). "Lebanon in my mind. The civil war and the centrality of th Lebanese-Armenian community in the making of the Armenian Diaspora nationalism". A. Boudjikanian (Eds.) Armenians Of Lebanon: From Past Princesses and Refugees to Present-Day Community, Beirut: Haigazian University, 415 
de dünyadaki topluluklardan öğrenci barındıran Ermeni okullarıyla bir doruk noktasına ulaşmıştır. Öte yandan, yeni radikal nesil Ermeniler, "ulusal dava" anlayışıyla Filistin örneğinden etkilenmişlerdi. Bu anlamda "merkeziyet", merkezdeki "vatan” ve "çevre" nin etnik-ulusal topluluklardan oluştuğu Ermeni de dâhil olmak üzere tüm modern diasporalar için uygun olan ulusal kimliğin merkez-çevre görüşünü ifade etmektedir. Nitekim diasporanın modernitesi, milli kimliğin gerçek hayatta ya da hayali anavatana bağlandığı fikrine dayanan bir topluluk örgütünün yapılandırılmasından ibarettir. Ancak hayali argüman, hayatta kalma ve gelișmenin yegane garantörü olmuștur. Diasporalar, "bir gün yurda dönmek" tasavvuru üzerine kurulmuştur. Dolayısıyla Lübnan Ermeni Diasporası, yukarıda belirtilen kültürel ve siyasi nedenlerden dolayı dikkat çekmektedir. ${ }^{59}$.

Lübnan'daki Ermeni Diasporasının oluşum sürecinden beri Ermeni cemaatinin karmaşık katmanları ve vatan ile olan ilişkileri oldukça tartışmalıdır. Bir ulus olarak Lübnan'a ait olmaktan ziyade Ermeni ulusuna ait olmak çok daha subjektiftir. Tarih, dil, semboller, efsaneler ve gelenekler, Ermeni anavatanıyla ilgili herhangi bir deneyime kıyasla çok daha alakalı olabilmektedir. Ermeniler şimdi “evsahibi” ülkede kendi koşullarıyla yaşamlarını sürdürmek için Lübnan'da evde kalabileceklerini düşünmektedirler. Örneğin Taşnak partili Pakradounyan; "Ermeni Lübnanlı ve Ermeni olmayan Lübnanlılar arasındaki fark başka bir dil bildiğimizdir." olarak bu kimlikleşmeye vurgu yapmaktadır. Bu biraz basitleştirici olsa da, Ermenilerin aynı anda kendi kurumlarını da koruyarak Lübnan topluluğuna tam olarak entegre olduklarını göstermektedir. $\mathrm{Bu}$ eğilimler, bugün vatan ile olan ilişkiler açısından önemli etkileri olan ayrı bir Lübnanlı Ermeni kimliğinin gelişmesine katkıda bulunmuştur ${ }^{60}$.

1950’li yılların başında Lübnan'daki Ermeni toplumu arasında bölünmeler ortaya çıkmıştır. Bu bölünmenin iki temel fraksiyonu; tarihi ve coğrafi faktörler olmuştur. Birinci grup kendilerini; "Diaspora Ermenileri” ikinci grup; "Yerli Ermeniler" olarak adlandırmaktadır. ${ }^{61 .}$ Diaspora Ermenileri, Lübnan’a Sevk ve İskân kanunu ile birlikte Osmanlı Devleti'nin muhtelif illerinden göç eden Ermenilerdir. Sayısal olarak Lübnan'daki Ermeni nüfusunun \%80\%85 'ini oluşturan en büyük gruptur. Bu grup kendilerini; "Kilikya Ermenileri” olarak da adlandırmaktadır. Türkiye Cumhuriyeti kurulmadan önce Osmanlı Vilâyetleri olan Adana ve Halep'te yaşayan bu Ermeniler, 1920'li yılların başında Lübnan'da 25.000 kadar bir nüfusa sahip olmuşlardır. Diaspora Ermenilerinin ikinci alt grubu olan ve kendilerini "Anadolu Ermenileri" olarak adlandıran Ermeniler, Türkiye'nin batısındaki önemli merkezlerden gelmişlerdir. Lübnan'daki Ermenilerin \% 20’sini oluşturan bu Ermenilerin 8.000'e yakın nüfusları vardır. Diaspora Ermenilerinin üçüncü alt grubu olan Ermeniler ise; Lübnan'ın mahallî bölgelerinde yer alan Katolik Ermenilerdir'62. Lübnan'daki Ermenilerin ikinci bir grubu olan Yerli Ermeniler, Batı ya da Doğu'da doğmuş ya da yetişmiş olan ve 1920'li yıllarda Lübnan'da olan 5.000 kadar nüfusa sahip Ermenilerdir. Lübnan’daki Ermeni nüfusun yaklaşık

59 Ghoukassian, K. D. (2009). "Lebanon in my mind. The civil war and the centrality of th Lebanese-Armenian community in the making of the Armenian Diaspora nationalism". 416

60 Krikorian, M. R. (2007). Almost Home: Perceptions Of Home And Homeland Among The Armenian Diaspora In Lebanon. 55

61 Schahgaldian, N. B.(1979). The Political Integration of an Immigrant Community Into A Composite Society: The Armenians In Lebanon 48.

62 Schahgaldian, N. B.(1979). The Political Integration of an Immigrant Community Into A Composite Society: The Armenians In Lebanon. 48. 
\%12'sini olușturmaktadırlar ${ }^{63}$.

Ermeni Diasporası, Lübnan sosyal yapısına önce ekonomik, daha sonra siyasi ve nihayetinde sosyo-kültürelolarakentegre olmuştu. Bu entegrasyonun başlıcagöstergelerinden biri, Lübnan-Ermeni kimliğinin asıl meydan okuması bağımsız Ermenistan'ın yeniden doğuşu ve "hayrenik" kavramının simgesel ve ritüel alanından gerçek haline dönüşmesidir ${ }^{64}$. Hayrenik (anavatan) ve Hayastan'ı (Ermenistan) tanımlayan ve ayıran fikirler sembolik ya da fiili / pratik olsun yeni bir anlam kazanmıștır ${ }^{65}$. Yukarıda da değinildiği gibi Lübnan, Ermeniler açısından "our second homeland (yergrort hayrenik/İkinci Vatan)" olarak tasvir edilmektedir. Geri dönüş kavramının kimlik kazanma değeri dışında, "anavatana geri dönme" kavramının oynadığı bir başka işlev, çeşitli Diasporik örgütlerin rolünü meşrulaştırmaya yardımcı olmasıdır. Şöyle ki; değer, kültür ve gelenekleri ile ulusun geri dönüş zamanı gelene kadar Diasporik örgütlerin bu algı pratiğinde vatana ulaşılabilirliği olarak görülmüştür ${ }^{66}$.

\section{SONUÇ}

Diaspora kavramının, tanım, sınıflandırma ve mevcut faaliyet noktasından yola çıkılarak diasporanın göç ve asimilasyonun teolojik ve ulus-devletçi anlayışlarına bir alternatif sunduğu ileri sürülmüştür. Ancak diaspora konusunda kavramsal olarak net bir konsept oluşmamıştır. Birçok milliyetçi hareketin öz olarak kabul ettiği 'Gerçek kimlikler' hakkındaki varsayımları ile uluslar üstü aidiyet duygusunu yeniden inşa etmek ve küresel düzeyde gerçekleşen hareketleri diasporadaki mevcut anlayış ekseninde ortaya çıkarmak zorlaşmıştır. Ayrıca çeşitli diaspora gruplarının hem diaspora hem de ev-devlet çevreleri tarafından yönlendirilen karşı iddialara sahip olması durumunda, diasporaların devlet dışı aktörler olarak özerkliği ne derecede olduğu belirsizdir. Dolayısıyla diasporaları kimlik temelli aktörler olarak kuramsallaştırmak veya ulus ötesi toplumsal hareketlerinin ve mevcut teorik yaklaşımlarının üzerinden eleștirel anlamda incelemek gerekmektedir.

Ermeni Diasporası, 1915 yılı ve sonrasında tanımlanmıştır. Diasporada inşa edilmiş ve idealize edilmiş bir ulusal geçmişi temel alan "anavatan" vizyonuyla mutabık kalınmıștır. İkinci Dünya Savaşıından sonraki yıllarda "vatan", Sovyet yetkilileri ve Diaspora örgütleri tarafından desteklenen bir stratejiye dönüşmüștür. Şöyle ki; Sovyet Ermenistan'ı, otoriter bir ulusal ev olarak meşrulaştırmak ve ülkeye geri dönüşü özendirmek için "anavatan" kavramı üzerinde propagandalar idealize edilmiştir. Bu yolla Ermeniler, Yahudiler gibi, atalarından bir vatanın geri dönüşüne dair ortak bir rüyanın anahtar niteliğini taşıyan bir arketip diasporasına dönüşmüștür. Diasporada, kimlik koruma ve Soykırım tanımaya odaklanan geleneksel gündem varlığını devam ettirmektedir. Diaspora toplulukları, örgütlü ve gayri resmi faaliyetler vasıtasıyla birbirleriyle aktif olarak bağlar kurmayı amaçlamışlardı. Özellikle 1991'de Ermenistan Cumhuriyeti'nin bağımsızlığı, Diasporanın "ev sahibi" devletlerde giderek

63 Schahgaldian, N. B.(1979). The Political Integration of an Immigrant Community Into A Composite Society: The Armenians In Lebanon.49.

64 Kotchikian, A. (2009). "Between (Home)land Lebanese- Armenians and the Republic of Armenia”. Armenians Of Lebanon: From Past Princesses and Refugees to Present-Day Community, A. Boudjikanian (Eds.) Armenians Of Lebanon: From Past Princesses and Refugees to Present-Day Community, Beirut: Haigazian University, 47576.

65 Kotchikian, A. (2009). "Between (Home)land Lebanese- Armenians and the Republic of Armenia". 466.

66 Kotchikian, A. (2009). "Between (Home)land Lebanese- Armenians and the Republic of Armenia”. 467. 
daha kök salmasına ve daha sivil katılımın sağlanmasına neden olmuştur. Aynı zamanda Ermenistan'a yönelik bir yönelimin yanı sıra, ulus aşırı sembolü olan 'vatan' anlayışının geleneksel Diaspora yaklaşımıyla yeniden canlandırılmasına da neden olmuştur.

Kimlik koruma konusundaki kurumların araçsal rolünü vurgulayarak, Lübnan'da Ermeni Kilisesinin nihai meşruluğa sahip olduğunun vurgulanması gerekmektedir. Dolayısıyla Kilise, Lübnan kurumsal yapısı tarafından Lübnan'da yaşayan Ermenilerin gündelik hayatını yöneten organ olarak yetkilendirilmektedir. Dahası, Lübnan'daki Ermeni kilisesinin kendi zinciri Ermeni okulları, gençlik / öğrenci organizasyonları var ve Lübnan'da Ermenilerin hayatlarını yönetmek için diğer kurumlar ve siyasi partilerle işbirliği yapmaktadır. Merkezde bulunan Kilise, diğer örgüt türleri ile işbirliği yapmakla birlikte onları Lübnan'da Ermeni kimliğini korumak ve güçlendirmek için görevlerini etkili bir şekilde yerine getirmelerinde etkili olmaktadır. Bu model, farklı Ermeni örgütlerinin ve partilerinin koordinasyonunu ve etkileşimini mümkün kılan dinamik bir platform yaratılmasına yol açmıştır. Kimliğin korunmasının "sırrı" nı Lübnan'da olması birçok yönde güçlü bağların varlığından kaynaklanmaktadır. Kiliseden okullara, siyasi partilere ve STK'lara kadar her kurumun arasındaki döngüsel bağlar bu birlikteliği teyit etmektedir.

\section{KAYNAKLAR}

\section{Arşivler}

Amerikan Arşivleri

General Central İntelligence Agency Records

General CIA Records, CREST, CIA-RDP80-00809A000700030265-3.

İngiliz Arşivleri

Foreign Office and Foreign and Commonwealth Office records

Foreign and Commonwealth Office(FCO)

FC09/3073/WST 245/1.

\section{KAYNAK ESER VE INCELEMELER}

Abramson, S. (2013). "Lebanese Armenians; A Distinctive Community In The Armenian Diaspora And In Lebanese Society”. The Levantine Review 2 (2), 188-216.

Akçam, T. (2000). Ermeni Tabusu Aralanırken: Diyalogdan Başka Bir Çözüm Var mı?. İstanbul: Su Yayınları.

Alfred, M.V. (2015). “Diaspora, Migration, and Globalization: Expanding the Discourse of Adult Education". New Directıons For Adult And Contınuıng Educatıon, 87-97. 
Anderson, B. (1991). Hayali Cemaatler Milliyetçiliğin Kökenleri ve Yayılması. (Çev:İskender Savaşır), İstanbul: Metis Yayıncılık.

Baibourtian, A. (2009). "The Emergence of the Armenian Diaspora and Genesis of the Indo-Armenian Community". Diaspora Studies, 2(1), 93-108.

Björklund, U. (2003). "Armenians of Athens and Istanbul: the Armenian diaspora and the 'transnational' nation". Global Networks 3, 337-354.

Brubaker, R. (2005). “The 'Diaspora' Diaspora”. Ethnic and Racial Studies, 28(1), 1-19.

Brınkerhoff, J. M. (2011). “David And Goliath: Diaspora Organizations As Partners In The Development Industry”. Public Administration And Development Public Admin, 31 (1), 37-49.

Cavoukian, K. (2013). "Soviet mentality?" The role of shared political culture in relations between the Armenian state and Russia's Armenian diaspora". Nationalities Papers, 41 (5), 709-729.

Cohen, R. (2008). Global Diasporas. New York: Routledge.

Gallo, E. (2010). "Diaspora by Design? Multiple Allegiances and Belonging in Contemporary Global Catholicism". Diaspora, 19(1), 51-73.

Ghoukassian, K. D. (2009). "Lebanon in my mind. The civil war and the centrality of th Lebanese-Armenian community in the making of the Armenian Diaspora nationalism". A. Boudjikanian (Eds.), Armenians Of Lebanon: From Past Princesses and Refugees to Present-Day Community, Beirut: Haigazian University, pp. 411-430.

Hediger, D. and Andrej L.( 2009). The Armenian quarters in Beirut Bourj Hammoud and Karm el Zeitoun. Draft ETH. Basel: Eidgenössische Technische Hochschule Zürich, Studio.

Laçiner, S. (2013). Ermeni Sorunu, Diaspora ve Türk Dış Politikası. Ankara: Usak Yayınları.

Laycock, J.(2012) “Armenian Homelands And Homecomings, 1945-9”. Cultual And Social History, 9 (1), pp.103-123.

Kasbarıan, S. (2013). “Diasporic Voices from the Peripheries - Armenian Experiences on the Edges of Community in Cyprus and Lebanon”. The Cyprus Review, 25 (1) , 81-110.

Koinova, M.(2011) "Diasporas and secessionist conflicts: the mobilization of the Armenian, Albanian and Chechen diasporas". Ethnic and Racial Studies, 34(2), 333-356.

Kotchikian, A. (2009). “ Between (Home)land Lebanese- Armenians and the Republic of Armenia". Armenians Of Lebanon: From Past Princesses and Refugees to Present-Day Community, A. Boudjikanian (Eds.) Armenians Of Lebanon: From Past Princesses and Refugees to Present-Day Community, Beirut: Haigazian University, pp. 463-476. 
Krikorıan, M. R. (2007). Almost Home: Perceptions Of Home And Homeland Among The Armenian Diaspora In Lebanon, Unpublished Master's Thesis, American Unıversity Of Beirut, Beirut.

Messerlian, Z. M. (1963). Armenian Representation In The Lebanese Parliament, Unpublished Master's Thesis, American University of Beirut, Lebanon.

McKittrick, K. (2009). “Diaspora”. R. Kitchın N. Thrıft (Eds.), International Encyclopedia of Human Geography, Canada: Elsevier, pp.156-161.

Policy Forum Armenia. (2010). Armenia-Diaspora Relations: 20 Years Since Independence. Armenia: A publication of Policy Forum Armenia.

Rana, Mohammad B., Elo, M. (2017). "Transnational Diaspora and Civil Society Actors Driving MNE Internationalisation: The Case of Grameenphone in Bangladesh". Journal of International Management, 23(1), 87-106

Singh, M., Singh A.(2008). "Diaspora, Political Action, and Identity: A Case Study of Canada's Indian Diaspora”. Diaspora, 17 (2), 149-171.

Schahgaldian, N. B.(1979). The Political Integration of an Immigrant Community Into A Composite Society: The Armenians In Lebanon 1920-1974. Unpublished Doctoral Dissertation, Columbia University, Columbia. Press.

Sheffer, G. (2010). Diaspora Politics At Home Abroad. Cambridge: Cambridge University

Skulte-Ouaiss, J., Tabar, T. (2014). "Strong in Their Weakness or Weak in Their Strength? The Case of Lebanese Diaspora Engagement with Lebanon, Immigrants \& Minorities Historical Studies in Ethnicity". Migration and Diaspora, 33(2), 141-164.

Ter-Matevosyan, V., Danielyan, H., Sisserian SV., . Kankanyan N., and Shorjian, N. (2017). "Institutions and identity politics in the Armenian diaspora: the cases of Russia and Lebanon". Diaspora Studies, 10 (1), 64-80.

Yamashiro, J. H. (2013). "Working towards conceptual consistency in discussing 'diaspora' and 'diaspora strategies': Ethnicity and affinity in the case of Japan". Geoforum 59, 178-186.

Yousefian, S.N. (2014). "Picnics for Patriots: The Transnational Activism of an Armenian Hometown Association". Journal of American Ethnic History, 34 (1), 31-52. 


\section{EKLER}

\section{Ek-1 Ermenilere dair İngiliz Foreign Office departmanı raporu.}

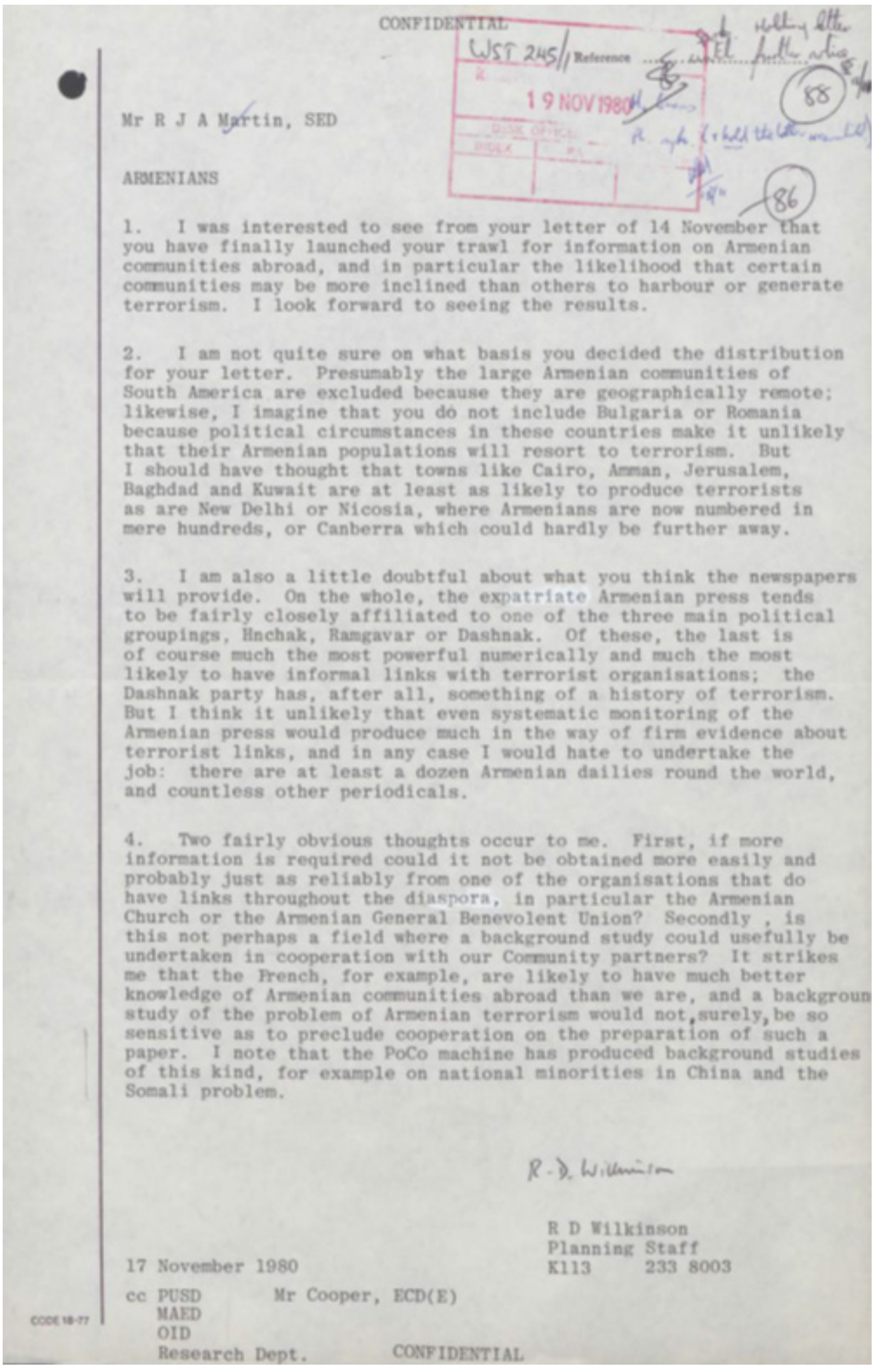


Ek-2 Taşnak Partisi'nin ideolojik yapısına dair bir CIA raporu.

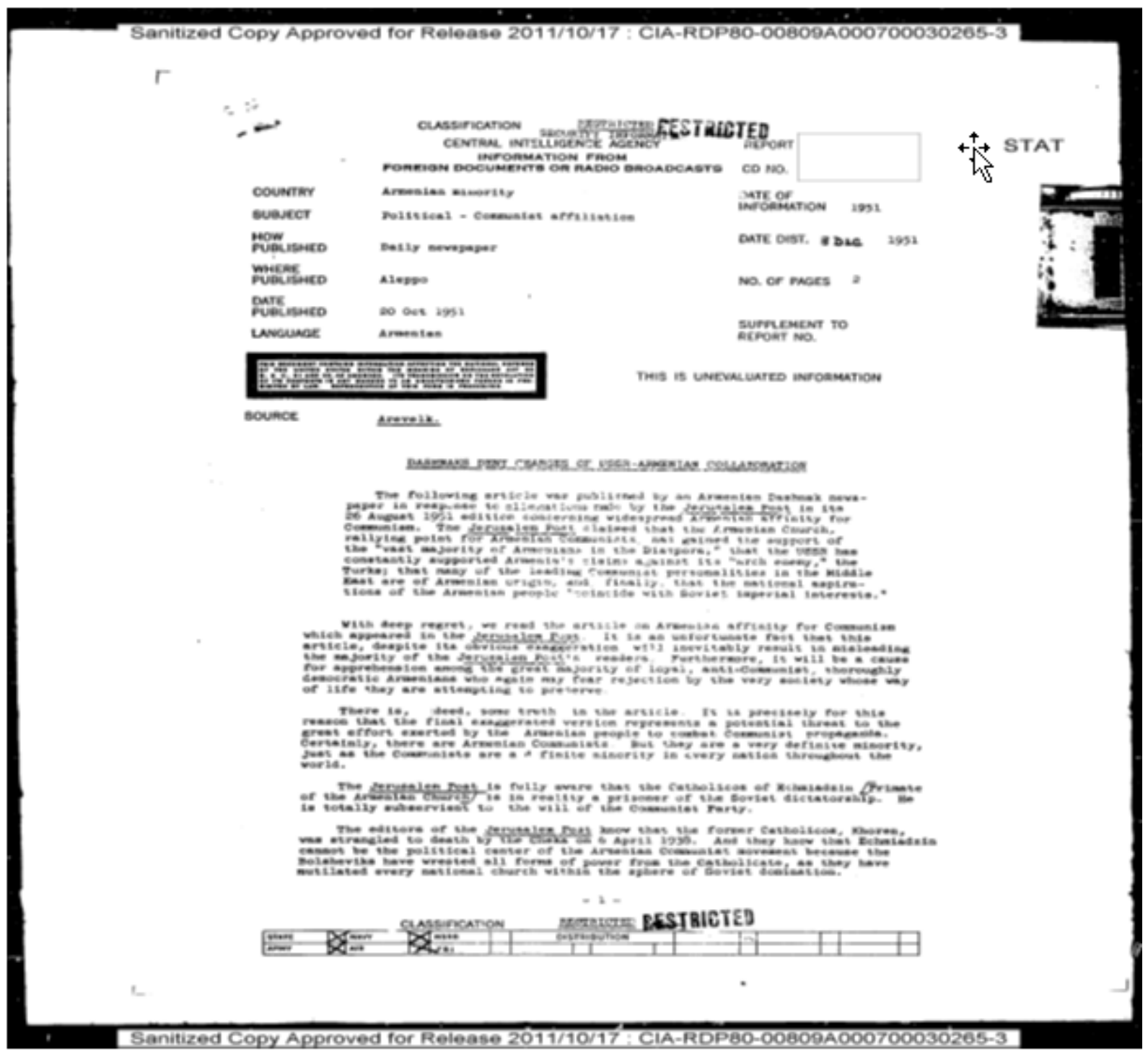


Ek-3 Lübnan'daki Ermeni yerleşim yeri (Bourj Hammoud).

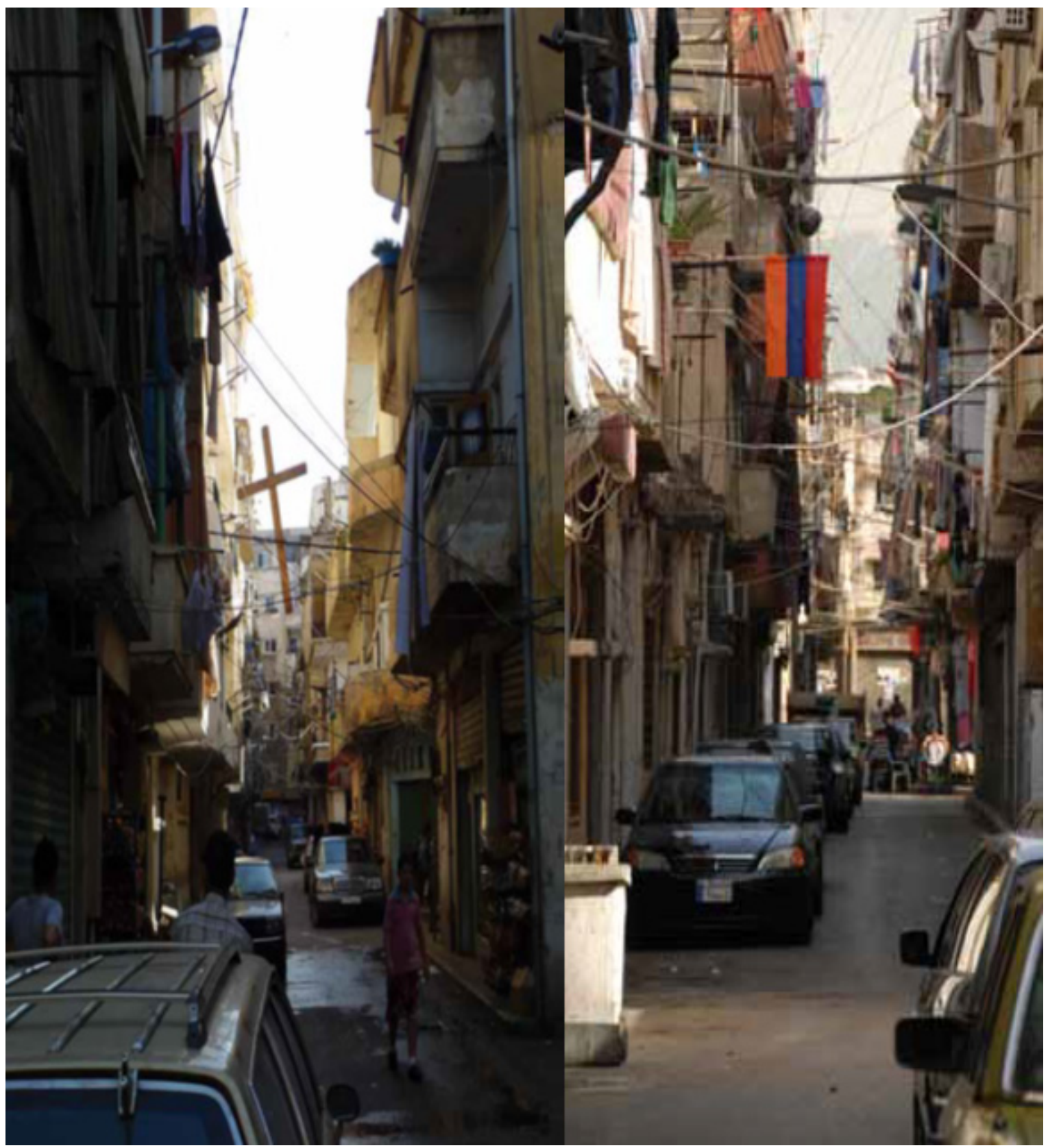

Hediger, D. and Andrej L.( 2009). The Armenian quarters in Beirut Bourj Hammoud and Karm el Zeitoun. 143. 
Ek-4 Lübnan'daki Ermeni Kiliseler.
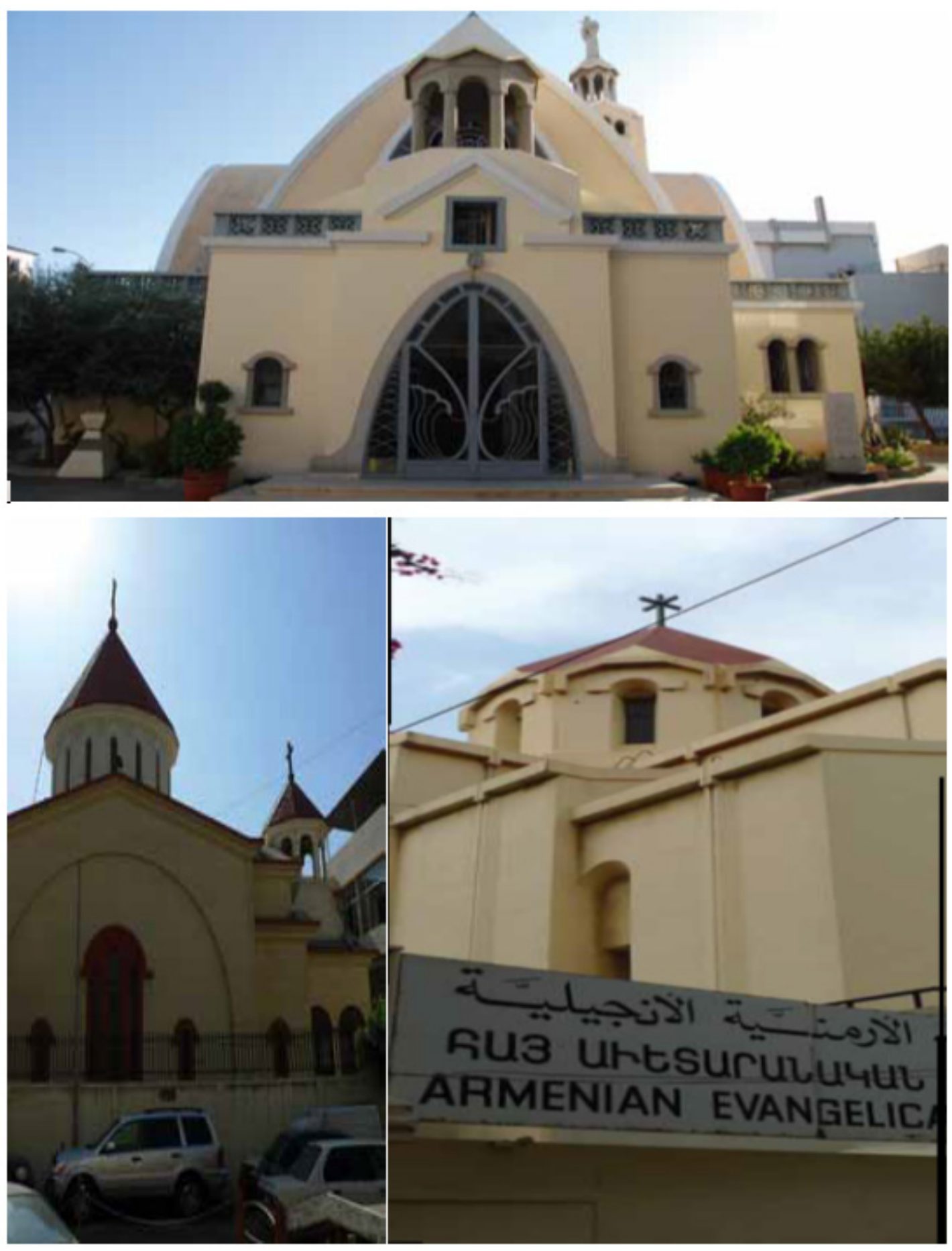

Hediger, D. and Andrej L.( 2009). The Armenian quarters in Beirut Bourj Hammoud and Karm el Zeitoun. 146. 